\title{
EFEKTIVITAS MODEL PEMBELAJARAN INKUIRI TERHADAP KEMANDIRIAN BELAJAR SISWA DI RUMAH
}

\author{
Oleh \\ Irfan Sugianto $^{1)}$, Savitri Suryandari' ${ }^{2)}$, Larasati Diyas Age ${ }^{3)}$ \\ 1,2,3Pendidikan Guru Sekolah Dasar, Fakultas Bahasa dan Sains, \\ Universitas Wijaya Kusuma Surabaya \\ Email: ${ }^{1}$ irfansugianto45@gmail.com, ${ }^{2}$ Savitri.suryandari69@gmail.com \& \\ 3larasatiage@yahoo.co.id
}

\begin{abstract}
The goal of learning independence is the curiosity of each student to find new things, which will encourage students to continue to look for problem solving so that in this case the independence of student learning is inseparable from the effectiveness of the learning model applied by the teacher. This research uses library research methods and the type of data used is secondary data. The literature review and from previous research data it can be concluded that inquiry learning towards student learning independence can be applied at school.
\end{abstract}

Keywords : Inquiry Learning Model \& Learning Independence

\section{PENDAHULUAN}

Siswa mampu berfikir dan melakukan usaha sendiri ketika mengalami berbagai macam keadaan di lingkungannya dan akhirnya siswa bisa belajar secara mandiri. Sikap kemandirian belajar siswa ini mampu melakukan sesuatu tanpa bantuan teman maupun orang di sekelilingnya sampai siswa bebas melakukan apapun yang diinginkan akan tetapi fokus akan penyelesaian masalah yang dihadapi.

Aspek kepribadian kemandirian belajar siswa sangat berarti, sebab pada saat menjalankan aktivitas setiap hari tidak pernah lepas melalui tantangan maupun cobaan. Siswa yang mempunyai usaha sendiri dalam kegiatan belajar yang relatif banyak akan bisa memecahkan segala persoalan yang dimiliki sebab siswa yang mempuyai kemandirian belajar tidak bergantung kepada orang di sekelilingnya melainkan tetap berusaha untuk menempuh dan mengatasi pemasalahan yang terus datang

Kemandirian belajar memerlukan tanggung jawab, memiliki inisiatif berpikir, mempunyai tekad yang kuat dan mampu menerima akibat yang ditimbulkan. Siswa dijadikan sebagai pebelajar bagi dirinya sendiri agar siswa mampu berusaha dengan tekun pada saat kegiatan belajar sekolah. Sejak awal dari pemberian tugas belajar yang disampaikan guru, maka siswa harus memiliki tekad yang kuat di dalam pikirannya agar semangat belajar yang timbul akan memunculkan ide kreatif serta dapat berinovatif.

Permasalahan yang terjadi pada era ini adalah dari segi kemandirian belajar siswa, yang memiliki nilai rendah di dalam kelas, yang akan menyebabkan siswa sulit mengatur waktu dalam belajar, tidak dapat mengatur arah tujuan serta tidak bisa melangkah yang harus diperbuat dalam menyelesaikan tugas dari seorang guru. Mewujudkan hal tersebut perlu adanya kemauan yang tinggi dari setiap siswa.

Kurangnya siswa dalam kemandirian belajar bisa dibuktikan dengan siswa yang tiada termotivasi agar belajar mandiri, tidak ulet dalam belajar, tidak serius, tidak disiplin serta tidak bertanggung jawab dengan sesuatu yang dikerjakan. Sebaliknya jika kemandirian belajar siswa terbentuk akan sangat memiliki kemauan dan keingintahuan siswa mengenai pengetahuan semakin berkembang dan maju.

Tujuan dari kemandirian belajar adalah keingintahuan setiap siswa untuk menemukan hal-hal yang baru, maka pasti membawa murid agar tetap senantiasa mencari penyelesaian masalah sehingga dalam hal ini kemandirian 
belajar siswa tidak terlepas pada efektivitas model pembelajaran yang diaplikasikan untuk pendidik. Model pembelajaranbisa dijadikan untuk pandauan dan acuan guru, sehingga dapat merangsang siswa untuk aktif dan mandiri dalam mengikuti pembelajaran.

Salah satu aspek agar siswa dapat bersikap mandiri dalam aktivitas pembelajaran yaitu dengan model pembelajaran. Model pembelajaran ini yang bakal menunjang daya ingat siswa lebih berkembang.

Berbagai model pembelajaran bisa diaplikasikan melalui cara pengkajian agar dapat meningkatkan kemampuan untuk memecahkan masalah dan menuntut untuk kemandirian belajar. Salah satunya model pembelajaran yang akurat dan cocok dimanfaatkan sebagai kemandirian belajar yaitu model pembelajaran inkuiri.

Model pembelajaran inkuiri adalah cara mengajar yang bisa meningkatkan kemandirian belajar murid di sekolah. Model pembelajaran inkuiri ini memposisikan murid untuk bertamba luas daya fikir secara matang.

Murid yang mampu belajar sendiri ini haruslah mampu percaya diri untuk menyampaikan informasi yang ditemukan kepada temannya. Guru bisa memberikan motivasi kepada murid agar bisa termotivasi dengan giat

Mengenai pendapat dari penulis, bahwa model inkuiri merupakan sebuah aktivitas dalam proses belajar mengajar yang mampu menciptakan cara berfikir ilmiah oleh siswa agar dalam kegiatan pembelajaran, mampu memecahkan masalah yang terjadi saat ini sehingga memperoleh pemahaman yang cukup kuat. Siswa bisa meningkatkan pemahamannya sehingga menyalurkan idennya ke orang lain.

Salah satu kelebihan model pembelajaran inkuiri melalui pendapat dari Hamruni (2012) adalah mampu melayani kebutuhan siswa yang memiliki kemampuan diatas rata-rata, artinya siswa yang mempuyai kapasitas dalam pembelajaran yang baik, tidak pernah membatasi dari kemampan siswa di sekitarnnya serta dapat memunculkan sebuah ide kreatif pada pembelajaran meskipun diterapkan di rumah masing-masing siswa. Siswa bisa memiliki daya ingat yang kuat

Sumber data yang diperoleh dari Falah Yunus, 2011 dengan judul "Korelasi Antara Sikap Terhadap Model Pembelajaran Inkuiri Dan Kemandirian Dengan Hasil Belajar Mata Pelajaran PKn Pada Materi Globalisasi Siswa Kelas IX SMP Negeri 50 Samarinda Tahun Pembelajaran 2010/2011. Hasil dari penelitian menemukan bahwa terdapat hubungan yang positif signifikan antara Sikap Terhadap Model Pembelajaran Inkuiri (X1) dengan Hasil Belajar Mata Pelajaran PKn Siswa (Y) dengan koefisien y1 $=0,362$ dan ditemukan persamaan regresi linier 0,235 X1 Y 5,570

Berdasarkan hasil skripsi dari penelitian Imam Mashuri pada Tahun 2012 membuktikan bahwa ada hubungan kemampuan pemahaman konsep dan kemandirian belajar melalui model pembelajaran inkuiri. Hal ini relevan dengan judul penelitian tentang "Pengaruh Pembelajaran Berbasis Masalah Dan Inkuiri Ditinjau Dari Kemandirian Belajar Siswa Kelas X SMA Negeri Kabupaten Blora”. Peneliti ini menyatakan bahwa pada siswa dengan kemandirian belajar tinggi melalui model pembelajaran inkuiri menghasilkan prestasi belajar matematika yang lebih baik. Penyelidikan ini adalah penyelidikan eksperimental semu atau memakai data kuantitatif

Berdasarkan judul dan data diatas, menyatakan bahwa kemandirian belajar bisa ditingkatkan dan diterapkan melalui model pembelajaran inkuiri ini. siswa yang bisa memahami tentang model pembelajaran inkuiri dan kemandirian belajar ini, dapat memiliki daya ingat yang kuat dan bisa cepat respon di dalam kelas

\section{LANDASAN TEORI \\ Definisi Model Pembelajaran Inkuiri}

Mengenai pendapat dari Hamdayama (2014) maka model pembelajaran inkuiri adalah cara di dalam aktivitas pendidikan agar semakin mengetahui serta mendapatkan alasan 
dari ide pemikiran siswa sendiri. Jadi siswa harus berusaha sendiri tanpa ikut campur dari orang lain

Menurut pengertian dari Ambarjaya (2012) mengenai model pembelajaran inkuiri adalah hubungan aktivitas pendidikan dalam cara tanggap serta sistematis agar mengetahui maupun mendapatkan balasan dari suatu masalah yang dimiliknyai. Jadi siswa harus memiliki cara berpikir yang reseptif

Mengenai beberapa teori di atas, bahwa menurut penulis dari pengertian model pembelajaran inkuiri adalah rangkaian dari suatu pengkajian yang melibatkkan seluruh siswa agar berfikir secara teliti, analogis dan sistematis sehingga bisa memecahkan masalah yang dihadapinnya. Jadi siswa harus aktif pada saat pembelajaran berlangsung

\section{Ciri-ciri Model Pembelajaran inkuiri}

Berdasarkan pendapat dari Hamiyah dan jauhar (2014) mengemukakan ciri-ciri model pembelajaran inkuiri yaitu : (1) Mempuyai akibat menjadi aplikasi model pembelajaran baik secara tepat langsung maupun tidak tepat, (2) Mempuyai alat di fase model pembelajaran inkuiri ini, (3) bisa diselesaikan dengan arahan agar pemeriksaan pada aktifitas pembelajaran di ruang tertutup (4) Memiliki tugas atau arah dari pendidikan tersendiri, (5) mengenai konsep pendidikan dan konsep menuntut ilmu.

Tanggapan dari Hosnan

(2014)

mengemukakan bahwa ciri-ciri model pembelajaran inkuiri antara lain: (1) Arah pada pemanfaatan model inkuiri adalah menumbuhkan daya bekerja sebagai teratur, tersusun dan tanggap atau bisa menumbuhkan keahlian mental menjadi bidang mulai prosedur moral. Siswa harus mempunyai cara terampil untuk giat belajar. (2) Kegiatan yang dilaksanakan siswa diberikan petunjuk untuk mendapatkan dan menciptakan melalui materi yang mempertanyakan sampai menginginkan perilaku yang menyakinkan. Siswa harus mempunyai cara berpikir yang displin. (3) Mempertegas oleh kegiatan siswa dengan cara sebanyak-banyaknya agar memeriksa serta menciptakan dengan baik. Siswa bisa memahami materi pelajaran yang sudah diajarkan pada hari itu juga.

Berdasarkan beberapa teori di atas, bahwa menurut penulis, ciri-ciri model pembelajaran inkuiri antara lain : (1) Model inkuiri ini menyertakan seluruh peserta didik untuk dapat bekerja sampai rajin, produktif dan ada pembaruan maka pendidikan berfokus terhadap student center. Siswa bisa berfokus pada satu titik. (2) Pendidikan inkuiri ini, guru selaku penyedia dan memberikan arahan kepada peserta didik untuk selalu meningkatkan perilaku mandiri. Siswa bisa menambahkan idennya kepada teman yang lain. (3) Pendidikan inkuiri ini dilaksanakan lewat cara pertanyaan dan jawaban sesama guru dan peserta didik maka akan menyelesaikan persoalan maupun jalan keluar secara bersamasama. Siswa bisa memecahkan persoalan tersebut dengan benar.

Tahap - Tahap model pembelajaran inkuiri

Mengenai teori dari Novehasanah (2016), ada beberapa langkah dalam model pembelajaran inkuiri antara lain: (1)

Orientasi, adalah tindakan selama membimbing situasi atau keadaan pendidikan yang selalu respon. Guru mengontrol supaya peserta didik bisa melakukan sistem pendidikan dengan aturan yang berlaku. (2) Merumuskan Masalah, cara memperoleh peserta didik melalui permasalahan yang berhubungan dengan tebak-tebakan. Permasalahan yang diberikan merupakan permasalahan yang merangsang peserta didik agar berkerja untuk memberikan solusi terhadap persoalan serta peserta didik diarahkan agar menghasilkan balasan yang benar. (3) Meringkas Hipotesis, jawaban sementara pada suatu persoalan yang masih diselidiki. Siswa bisa memiliki daya ingat yang kuat. (4) Menghimpun Data, kegiatan memilah penjelasan yang diperlukan agar memeriksa hipotesis yang diusulkan. Siswa bisa menghimpun data dengan benar. (5) Memeriksa Hipotesis, cara memutuskan jawaban yang sudah cocok melalui data serta penjelasan yang didapat berlandaskan untuk menggabungkan data, (6) Meringkas 
Kesimpulan, cara menjelaskan kembali yang didapatkan berlandaskan dari memeriksa hipotesis. Siswa bisa memeriksakan kembali dengan benar.

Berdasarkan pendapat dari Ngalimun (2012), menyatakan bahwa ada beberapa langkah-langkah dalam model pembelajaran inkuiri antara lain: (1) Memperoleh dan mengartikan persoalan, siswa bisa memberikan solusi atas persoalannya. Siswa bisa memahami persoalan yang dihadapi. (2) Menguraikan Hipotesis, Siswa bisa memiliki tentang jawaban sementara. Siswa bisa memahami materi yang disampaikan oleh guru. (3) Memberikan informasi, siswa bisa memiliki informasi apapun dari orang lain. Siswa bisa meningkatkan daya ingat untuk berpikir. (4) Memeriksa dugaan sementara, siswa memiliki daya ingat yang kuat. Siswa bisa memahami materi yang telah disampaikan oleh guru. (5) Mengambil ringkasan, siswa memiliki kesimpulan untuk meringkas semua bacaan yang diambil. Siswa bisa meringkas dengan baik.

Mengenai pendapat dari teori di atas, maka tahap-tahap model pembelajaran inkuiri menurut penulis antara lain : (1) Adaptasi, siswa bisa beradapatasi dengan baik. Siswa memiliki kemampuan yang kuat. (2) Meringkas persoalan, siswa bisa menyimpulkan dari semua materi yang telah diajarkan. Siswa sudah memahami materi tersebut. (3) Menyebutkan dugaan sementara, siswa bisa menjawab dari jawaban sementara tersebut. Siswa memiliki kemampuan yang bagus. (4) merangkai bahan, siswa bisa mengolah kata dengan benar. Siswa bisa meningkatkan daya berpikir. (5) Mengukur teori, siswa membandingkan materi agar bisa mengalami peningkatan dalam pembelajaran. Siswa bisa memahami dengan cara berpikir analogis.

\section{Keunggulan Model Pembelajaran Inkuiri}

Tanggapan dari Hamruni (2012), menyatakan bahwa ada beberapa keunggulan model pembeajaran inkuiri, antara lain: (1) bisa mengayomi keinginan seorang murid yang mempuyai keahlian di atas semua, maka seorang murid yang mempuyai keahlian belajar baik, tidak akan terhalang melalui murid yang rendah dari pembelajaran. Siswa bisa memiliki kemampuan yang kuat untuk sekolah. (2) Melalui pertumbuhan intelektal belajar masa kini yang dijadikan belajar merupakan cara perbedaan perilaku melalui pengetahuan. Siswa bisa (3) Memperoleh peluang untuk peserta didik agar belajar tepat pada keyakinan belajarnya. Siswa bisa percaya diri atas kemampuannya. (4) Mempertegas untuk menumbuhkan aspek keaktifan, kehadiran dan keterampilan yang sama, maka pembelajaran rencana ini akan bertambah bermanfaat. Siswa bisa merencanakan hal tersebut dengan baik dan benar.

Mengenai teori di atas, bahwa menurut penulis, keunggulan model pembelajaran inkuiri antara lain : (1) Menolong pesera didik agar menumbukan dan memiliki keahlian melalui cara psikologis. Siswa bisa membangkitkan semangatnya untuk ke sekolah. (2) Peserta didik mendapatkan wawasan melewati individu maka bisa mengerti serta bisa memecahkan solusinya. Siswa bisa meningkatkan daya berpikirnya. (3) bisa membangun semangat siswa untuk belajar semakin rajin dan tekun kembali. Siswa memiliki kemampuan untuk belajar mengajar.

\section{Kekurangan Model Pembelajaran Inkuiri}

Pada model pembelajaran inkuiri terdapat kenakalan pada remaja dikarenakan belum memahami materi dari guru dan belum bisa menyelesaikan masalah yang dihadapi saat ini. Tanggapan dari Savitri Suryandari (2020) bahwa kenakalan remaja adalah kecenderungan remaja untuk melakukan tindakan melanggar aturan yang dapat mengakibatkan kerugian dan kerusakan baik terhadap diri sendiri maupun orang lain, yang perilaku tersebut tidak dapat diterima secara sosial oleh masyarakat dinilai suatu kelainan yang disebut kenakalan, maupun tindak kriminal.

Menurut pendapat dari Mulyasa dalam Susanti (2014) ada 2 kekurangan dari model pembelajaran inkuiri antara lain: (1) Rumit dari 
merencanakan pendidikan disebabkan oleh terhambatnya melalui kebiasaan peserta didik dalam pembelajaran. Siswa harus bisa memiliki kemampuan untuk semangat belajar. (2) Susah mengendalikan aktivitas serta tercapainnya dari peserta didik. Siswa harus bisa memiliki kemampuan untuk belajar secara aktif

Tanggapan oleh Sanjaya (2011), menyatakan bahwa ada beberapa kekurangan dari model pembelajaran inkuiri antara lain: (1) Apabila model pembelajaran ini dipakai, bahwa mengelola aktivitas serta tercapainnya peserta didik harus secara benar. Siswa memiliki ide yang cemerlang agar bisa menjadi orang yang aktif. (2) Model saat ini sangat rumit melalui persiapan pendidikan, sebab terambatnya dari berulang kali peserta didik dalam belajar. Siswa bisa mempuyai kemampuan untuk bisa meningkatkan motivasi bagi teman yang lain. (3) Biasanya melalui penerapan, pasti membutuhkan masa yang lama, maka guru merasa rumit mengkondisikan pada masa yang sudah dijadwalkan. Siswa harus memiliki kepintaran agar bisa berfikir secara kritis.

Mengenai beberapa teori di atas, bahwa menurut penulis, ada kekurangan dalam model pembelajaran inkuiri antara lain : (1) Lebih mengutamakan pengetahuan, perilaku dan keterampilan. Siswa harus lebih memaknai dalam kegiatan belajar mengajar. (2) Sulit mengontrol keberhasilan siswa dan memerlukan masa yang lama. Siswa bisa memiliki keharusan untuk belajar secara analogis. (3) Semua kategori untuk tercapainnya belajar, dapat disepakati pada cara pandang berfikir peserta didik agar memhami sumber pelajaran. Siswa bisa memiliki daya ingat yang kuat ketika berusaha belajar sendiri.

\section{Definisi Kemandirian Belajar siswa}

Menurut pengertian dari Haris Mujiman (2011) kemandirian belajar adalah aktifitas pembelajaran yang menekankan kesimpulan agar memimpin dalam perlombaan, serta menumbukan melalui perencanaan wawasan yang sudah dipegang. Penetepan kompetensi sebagai tujuan belajar dan cara pencapaiannya baik penetapan waktu belajar, tempat belajar, irama belajar, tempo belajar, cara belajar, sumber belajar, maupun evaluasi hasil belajar dilakukan sendiri. Siswa bisa belajar melalui keyakinan diri sendiri

Tangapan dari Desmita (2012) Kemandirian belajar merupakan cara situasi di mana manusia mempunyai keinginan berkompetens di depan agar kebajikan dari individu bisa menghasilkan ketetapan serta ada ide agar memberantas persoalan yang dimilikinya, mempuyai keyakinan diri sendiri serta mengikuti pekerjaan saat ini serta mampu menerima resiko tentang apa yang sudah diperbuat. Siswa harus bisa memberikan solusi terhadap permasalahan yang terjadi.

Mengenai beberapa teori sebelumnya, bahwa dari penulis, pengertian kemandirian belajar siswa adalah kegiatan belajar yang dipegang setiap manusia agar menggerakkan dirinya sendiri melalui daya fikir supaya bisa mencapai arah dari pembelajaran tersebut. Siswa bisa memberikan motivasi untuk diri sendiri agar tetap bisa kuat selama mengikuti proses pembelajaran.

\section{Cara dalam kemandirian belajar}

Rencana dalam kemandirian belajar adalah hubungan di dalam kegiatan mengajar antara guru dan siswa serta acuan seperti memberikan petunjuk setelah itu dijelaskan berdasarkan ideologi dan skema yang sudah ada. Rencana ini sudah dipastikan untuk menggapai target tertentu. Menurut Abdul Majid (2013) ada beberapa cara yang digunakan dalam kemandirian belajar, antara lain antara lain : (1) Memiliki maksud untuk belajar, macam dan tingkatannya. Siswa harus memiliki arti dalam kegiatan untuk bersekolah. (2) Upaya memberikan materi pembelajaran, siswa harus memiliki usaha yang kuat. Siswa bisa memahami materi yang disampaikan oleh guru. (3) Instrumen yang dipakai, siswa harus bisa memanfaatkan alat yang ada di sekolah. Siswa bisa meningkatkan daya ingat. (4) Harga yang dipakai, siswa bisa memikirkan kembali uang yang dipakai untuk masuk ke sekolah. Siswa bisa memiliki kecerdasan dalam belajar. (5) Durasi yang sudah dibatasi, siswa bisa mempertimbangkan waktu yang digunakan secara efisien. Siswa bisa mengatur waktu 
dengan baik. (6) Alur aktivitas dalam pembelajaran, siswa harus melihat prosedur yang sudah ada. Siswa bisa memahami materi oleh guru. (7) Alat dan tata cara untuk menilai, siswa harus memahami tata cara penggunaan untuk menilai agar bisa terarah kembali. Siswa bisa memahami materi yang disampaikan oleh guru.

Berdasarkan pendapat dari penulis, ada beberapa strategi dalam kemandirian belaar antara lain : (1) Disiplin dalam mengatur waktu, siswa di dalam sekolah harus displin terhadap waktu agar tetap digunakan dengan baik. Siswa bisa meningkatkan daya berpikirnya. (2) Memiliki semangat yang tinggi untuk mengikuti pembelajaran, siswa harus memiliki semangat agar bisa memperoleh pelajaran dengan baik oleh pendidik. Siswa bisa memiliki pengetahuan yang luas. (3) Mencatat hal-hal yang penting setelah itu dipelajari kembali, siswa harus mencatat dengan ringkas agar nantinya tidak kelupaan pada materi yang akan datang. Siswa memiliki kemampuan yang ideal dalam pemelajaran.

\section{Karakter Kemandirian Belajar}

Mengenai pendapat dari Babari (2012) ada lima karakter kemandirian belajar, antara lain: (1) Keyakinan, sikap yang harus dimiliki oleh siswa agar bisa berkompeten. Siswa bisa memahami materi oleh guru. (2) Bisa berusaha sekuat tenaga, siswa harus bisa berusaha sekuat tenaga untuk diberikan oleh guru. (3) Memahami bidang serta keahlian yang sama dengan tugasnya. Siswa harus bisa kerajinan agar bisa memiliki keahlian yang khusus di bidangnya. (4) Memandang peluang, siswa tidak boleh bergantung kepada orang lain. Siswa bisa memberikan perubahan yang lebih baik. (5) Menerima resiko, siswa harus menerima resiko, dari dalam kelas ataupun dari luar kelas.

Menurut Fatimah (2010) karakter kemandirian belajar antara lain (1) Kejadian manusia yang mempuyai keinginan dalam berkompetensi agar di depan untuk kebajikan individu. Siswa harus bisa menerima resiko yanag dibuat sebelumnnya. (2) Bisa mempuai ketetapan dan ide agar memecahkan persoalan yang dimilikinya. Siswa harus memiliki komitmen yang kuat. (3) Mempuyai keyakinan untuk membuat pekerjaan. Siswa harus bisa memberikan solusi yang terbaik. (4) Mampu menerima resiko tentang apa yang sudah diperbuat.

Berdasarkan beberapa teori di atas, bahwa menurut penulis, tentang ciri-ciri kemandirian belajar antara lain sebagai berikut : (1) Tidak menggantungkan orang lain, siswa harus berusaha sendiri. Siswa harus memiliki percaya diri yang kuat. (2) Mempuyai ide yang menarik dan cemerlang. Siswa harus memiliki terobosan yang baru agar bisa memberikan perubahan yang lebih baik. (3) Bisa memberikan solusi setiap ada permasalahan yang datang. Siswa harus memberikan jalan keluar pada saat ada persoalan.

Syarat-syarat Dalam Kemandrian Belajar

Syarat-syarat Kemandirian Belajar Menurut Prawiradilaga (2012) antara lain : (1) Memastikan ringkasan untuk menuntut ilmu. Siswa harus membuat kesimpulan dengan ilmu yang telah dimiliki (2) Bahan pengetahuan yang dipeluas secara perlahan-lahan dibentuk mengarah pada rancangan nasihat. Contoh setara dengan nasiat secara langsung dan tidak langsung (3) Bahan yang disampaikan adalah prosedur yang sempurna berupa mentargetkan pendidikan agar tetap maksimal. Siswa harus bisa mencapai targetan dari seorang pendidik agar bisa memahami materi pelajaran (4) Bahan yang mau diberikan untuk murid bisa lewat alat cetak atau internet. Siswa bisa memaksimalkan teknologi pada saat di sekolah (5) Pemberian bahan pelajaran bisa diakses melalui bantuan pos ataupun lewat jaringan komputer. Siswa bisa memaksimalkan keadaan bahan pelajaran yang sudah disediakan (6) Cara pemberian pembelajaran bisa mengunakan animasi yang bergerak sehingga membuat pelajaran semakin menarik. Siswa bisa memahami tentang animasi yang sudah ditentukan oleh seorang pendidik

Berdasarkan pendapat dari penulis, ada beberapa syarat-syarat dalam kemandirian 
belajar antara lain: (1) Merencanakan cara dan target yang dibutuhkan. Siswa bisa merencanakan cara dan target diatas agar siswa tidak tergesa-gesa untuk berangkat ke sekolah. (2) Siswa harus memiliki ide yang kreatif. Siswa harus mempuyai gagasan yang dapat meningkatkan daya berpikir. (3) Siswa bisa menganalisa data secara teliti. Siswa bisa menguraikan penyelidikan yang sudah diteliti sebelumnya.

\section{Faktor-Faktor Yang Mempengaruhi Kemandirian Belajar}

Hasil pemikiran pada Djaali (2017) menyatakan faktor-faktor internal yang mempengaruhi kemandirian belajar antara lain: (1) Konsep diri. Siswa terbiasa belajar apabila sudah memahami materi yang diperoleh oleh guru. (2) Motivasi. Siswa akan selalu mengembangkan minat yang sudah ada sebelumnnya (3) Sikap. Siswa mencerminkan perilaku yang postif apabila berada di kalangan masyarakat.

Sedangkan faktor eksternal yang mempengarvhi kemandirian belajar antara lain : (1) Lingkungan sekitar. Faktor sekitar ini yang bisa mempengaruhi siswa di sekolah (2) Faktor masyarakat. Faktor yang bisa memberikan bersikap positif oleh siswa. (3) Faktor sekolah. Faktor yang menentukan agar siswa bisa memberikan perubahan yang lebih baik dan (4) Faktor keluarga. Faktor yang paling menentukan dan paling utama supaya siswa memiliki dorongan di saat ke sekolah.

Berdasarkan beberapa teori di atas, bahwa menurut penulis, tentang faktor-faktor yang mempengaruhi kemandirian belajar antara lain sebagai berikut :

1) Faktor internal adalah faktor yang mempengaruhi kemandirian belajar siswa dari dalam, meliputi: (1) Disiplin, akan membuat siswa semakinpandai mengatur waktu. Siswa memahami karakter yang sudah dimilikinnya. (2) Percaya diri, siswa akan semakin berani dalam menghadapi masalah. Siswa bisa mengahdapi masalah yang dihadapi. (3) Dorongan, siswa akan semakin kuat untuk daya ingat di otak. Siswa bisa mempuyai wawasan yang luas. (4) Tanggung jawab, siswa akan memliki kemampan untuk menyelesaikan masalah. Siswa bisa bertanggung jawab atas persoalan yang dihadapi.

2) Faktor eksternal adalah faktor yang mempengaruhi kemandirian belajar siswa dari luar. meliputi : (1) Adat istiadat, siswa harus mengenal adat istiadat di daerahnya masingmasing. Siswa bisa memahami materi yang sudah disampaikan sebelumnnya.(2) Masyarakat sekitar, siswa bisa memberikan wadah perubahan untuk masyarakat menjadi lebih baik. Siswa memiliki kemampuan di atas rata-rata. (3) Kondisi alam, siswa harus menjaga alam yang ada di sekitarnya agar bisa terawat dengan sempurna. Siswa bisa memetik hasil yang sudah dimiliki atas kekayaan alam tersebut.

\section{Manfaat Kemandirian Belajar}

Manfaat Kemandirian Belajar Menurut Yamin (2013) antara lain sebagai beikut : (1) Memberikan kecerdasan kepada orang lain. Siswa harus bisa memiliki kepintaran untuk bisa berkopentendi dalam kelas maupun di luar. (2) Memperdalam penyelidikan. Siswa bisa memperdalam penyelidikan dengan tekun dan rajin. (3) Menanamkan cara untuk berusaha sendiri tanpa menggantungkan orang lain. Siswa harus bisa belajar sendiri tanpa ada bantuan dari orang lain. (4) Menambahkan daya ingat. Siswa harus bisa memperkuat daya ingat di dalam pikirannya. (5) Menambah pengalaman. Siswa harus bisa menambah wawasan dari teman maupun orang lain yang bisa bertkar pikiran (6) Menyelesaikan persoalan. Siswa dapat memberikan solusi pada setiap persoalan yang dihadapi. (7) Mempertimbangkan ketetapan. Siswa bisa memilih dan memilah terhadap keputusan yang diambil (8) Bisa berimajinatif. Siswa harus bisa mengembangkan idennya. (9) Bersikap teliti. Siswa harus bisa cermat terhadap persoalan apapun. (10) Meyakini diri sendiri. Siswa harus bisa percaya bahwa persoalan pasti ada solusinya. (11) Sebagai pelajaran buat diri sendiri. Siswa bisa mengevaluasi dirinya sendiri agar kedepannya bisa lebih baik. 
Berdasarkan pendapat dari penulis, bahwa manfaat kemandirian belajar antara lain : (1) Siswa lebih banyak wawasan yang disampaikan oleh guru sehingga siswa tidak kebingungan. Siswa harus mengupas semua pengetahuan dan selalu memahaminnya. (2) Siswa mendapat kepintaran apabila sudah memahami segalannya. Siswa harus bisa mengerti apa saja materi yang disampaikan oleh guru. (3) Siswa akan mendapatkan banyak teman apabila saling bekerjasama dengan teman yang lain. Siswa yang pintar akan dipedulikan oleh teman yang lain dikarenakan bisa membagi ilmunnya.

\section{Keunggulan kemandirian belajar}

Pada keunggulan kemandirian belajar, tidak terlepas dari peran dari Ilmu Pengetahuan Sosial ( IPS) yang dapat meningkatkan daya berpikir siswa di dalam pembelajaran. Siswa bisa berfikir secara kritis dan responsif apabila Ilmu Pengetahuan Sosial (IPS) diajarkan di sekolah.

Menurut Larasati (2020) Ilmu Pengetahuan Sosial (IPS) merupakan bagian dari dari kurikulum sekolah yang tanggungjawab utamanya adalah membantu peserta didik dalam mengembangkan pengetahuan, keterampilan, sikap, nilai yang diperlukan untuk berpartisipasi dalam kehidupan masyarakat baik di tingkat lokal, nasional maupun global. Dewasa ini IPS hanya dipahami sebagai disiplin ilmu yang mentransfer pengetahuan semata tanpa implementasi dari pengetahuan itu sendiri.

Menurut Uno B Hamzah (2012) menyatakan ada beberapa keunggulan kemandirian belajar antara lain : (1) Sistem untuk kegiatan pembelajaran dengan berusaha sendiri. melalui pemikiran yang teliti akan mendapatkan kegiatan pembelajaran secara luas dengan memaksimalkan buatan adalah butuh pertumbuhan. Baik dari aspek pembelajaran maupun dari daya berpikir siswa. (2) Bentuk ini akan menyampaikan peluang, baik melalui siswa lemah dalam ingatan maupun yang cepat untuk berpikir. dalam memberikan solusi yang tepat sehingga memiliki kemampuan berbeda-beda di setiap murid. Jadi harus bisa meberi daya ingat semakin kuat. (3) Menempuh dengan penuh keyakinan dan berusaha sendiri yang harus dimiliki oleh siswa agar tetap diikuti pada saat di sekolah yang nantinnya bisa memberikan perubahan di lingkungan sekitarnya. Siswa harus bisa memiliki keyakinan agar bisa memberikan perubahan. (4) Sistem belajar dengan berusaha sendiri maka bakal mengakibatkan lebih luas kepedulian terhadap siswa yang secara kelompok dan akan membuka peluang yang lebih besar untuk saling berkolerasi dengan siswa. Siswa harus bisa berkumpul dengan tema yang lain agar bisa menambah jaringan dengan baik. (5) Aktivitas dan kewajiban seorang guru yang berperan akan mengalami perubahan disebabkan durasi yang diberikan semakin kecil dan disamping itu pula durasi semakin luang untuk mengamati murid dalam pembelajaran di grup atau golongan serta bisa membantu pembelajaran lain di lain waktu. Siswa harus bisa saling mendukung agar tetap bisa berkontribusi dengan baik.

Berdasarkan pendapat dari penulis, bahwa keunggulan kemandirian belajar antara lain : (1) Siswa dipecaya oleh orang di sekitarnya. Siswa semakin disenangi oleh teman karena bisa belajar bersama. (2) Siswa tersebut bisa diandalkan oleh temannya. Siswa tersebut bisa dipercaya oleh orang lain. (3) Siswa tersebut bisa memberikan perubahan yang lebih baik di kalangan sekitarnya. Siswa bisa menadi pintar apabila semakin hari semakin berubah menjadi baik.

\section{Kekurangan Kemandirian Belajar}

Menurut Uno B Hamzah (2012)

menyatakan bahwa terdapat kelemahan kemandirian belajar antara lain : (1) Dikarenakan masih rendah mengenai sosialisasi dari guru kepada murid atau murid kepada murid yang lain ketika sistem pembelajaran menggunakan untuk cara satu satunya di proses pengajaran. Ada persiapan untuk aktivitas anggota yang sedikit melalui guru serta murid dalam harapan yang mau diinginkan. Siswa bisa memiliki keinginan 
untuk bisa menjadi orang yang cerdas akan tetapi masi ada kelemahan di dalam daya ingat.

(2) Ketika semata-mata digunakan dalam cara sendiri melalui tahap yang konsisten, tindakan dalam pembelajaran mendapatan kejenuhan serta tidak menyenangkan. Siswa bisa mengalami kebosanan pada saat mengajar. (3) Agenda untuk berusaha sendiri tidak tepat untuk dilakukan oleh seorang murid ataupun oleh guru. Siswa maupun pendidik terasa semakin berat dikarenakan beban yang dipikul terlalu berat.

Berdasarkan pendapat dari penulis, bahwa kelemahan kemandirian belajar antara lain : (1) Sebagian siswa yang bandel atau tidak memahami guru pada saat menyampaikan materi di kelas. Siswa terkadang emosi yang bisa menurunkan daya ingatnya. (2) Guru harus ekstra lebih keras terhadap murid yang memiiki daya ingat yang lemah dibandingkan dengan siswa yang memiliki daya ingat kuat. Siswa terkadang bisa sulit menerima materi yang disampaikan oleh guru.

\section{METODE PENELITIAN}

Penelitian ini memakai metode penelitian kepustakaan. Menurut Embun (2012) penelitian kepustakaan merupakan pengkajian yang berlandaskan pada karya tertulis yang sudah tercantum pada buatan pengkajian, baik yang sudah ataupun yang belum diterbitkan.

Menurut penjelasan dari Zed (2014) penelitian kepustakaan adalah penelitian buku, dengan pencarian bacaan yang tidak selalu dimulai dari tindakan untuk merencanakan konteks pengkajian melainkan dapat berguna untuk mengetahui peneliti agar mendapatkan informasi penyelidikan.

Jenis informasi yang diambil adalah melalui data sekunder. Metode pengambilan informasi yang diperoleh melalui studi pustaka. Metode ini hendak dilakukan untuk penelitian studi literatur.

Jadi penelitian kepustakaan ini adalah suatu pengkaian melalui studi literatur yang belum tentu mengaruskan seseorang praktek langsung dan bertatap muka dengan narasumber serta informasi yang diperlukan melalui pengkajian ini, bisa diambil melaui asal-usul bacaan maupun dari penelitian sebelumnnya. Data tersebut bisa digunakan untuk artikel ataupun jurnal

Penelitian studi literatur merupakan pengkajian yang sesuai melalui observasi yang berbeda melainkan berasal dari bahan acuan untuk memperoleh informasi di buku melalui memahami, menulis, serta mengerjakan alat observasi. Data tersebut bisa diamati dengan cermat dan teliti sehingga tidak sampai ada yang salah

Studi literatur ini mencari ketelitian agar bisa mendapatkan menganalisis informasi dan meringkas dari produk yang sama melalui arah yang diinginkan. Maka dari itu perlu mencari perencanaan serta penyelenggaraan secara sempurna.

Penyelidikan dengan studi literatur ini bisa disebutkan pada suatu karya ilmiah sebab memberikan informasi dilaksanakan melalui pendekatan dari cara rujukan informasi tertentu. Faktor ini melalui pengkajian studi literatur ini memiliki ciri yang bukan formal dan informasi didapatkan melalui ulasan sebagai terperinci pada pengarang.

\section{HASIL DAN PEMBAHASAN}

Kemandirian belajar siswa merupakan sifat atau perilaku yang dimiliki oleh siswa untuk tidak menggantungkan orang lain sehingga bisa mengerjakan kehendak dirinya sendiri dan bisa bertanggung jawab atas keputusan yang sudah diambil. Keputusan yang sudah diambil, atau sudah diberikan oleh siswa, maka harus bisa bertanggung jawab dan menerima resiko dengan lapang dada.

Siswa harus bersungguh-sungguh pada kegiatan pembelajaran agar bisa mengakhiri pekerjaan atau mata pelajaran yang dianjurkan oleh guru dengan baik dan analogis. Model pembelajaran inkuiri merupakan model pembelajaran vang membuat murid agar bersikap tanggap, analitis dan logis sehingga bisa memecakan masalah yang sedang dihadapi saat ini.

Ketika masalah sedang dihadapi oleh siswa, maka siswa harus berusaha untuk 
mencari solusi agar masalah tersebut bisa diselesaikan secara matang dan bisa berkomitmen secara penuh. Keterkaitan antara kemandirian belajar dan model pembelajaran inkuiri adalah sama sama memiliki komitmen untuk bertanggung jawab agar bisa memecahkan masalah.

Jadi semakin besar kemandirian belajar dari murid, maka semakin besar pula nilai yang diperoleh untuk memahami tentang model pembelajaran inkuiri ini. tujuan dari kemandirian belajar adalah keingintahuan setiap siswa untuk menemukan hal-hal yang baru, maka pasti membawa murid agar tetap senantiasa mencari penyelesaian masalah jadi mengenai keadaan ini kemandirian belajar murid tiada terlepas melalui efektivitas model pembelajaran yang ditaplikasikan oleh pendidik. Model pembelajaran bisa dijadikan untuk petunjuk dan acuan guru, sehingga bisa membawa murid agar bergerak dan mandiri untuk mengikuti pembelajaran.

Keterkaitan antara tujuan kemandirian belajar dengan model pembelajaran inkuiri adalah sama-sama untuk memecakan masalah, ketika siswa diberikan tugas dari seorang guru maka siswa sudah memahami materi yang telah diajarkan dan sudah disampaikan secara jelas dan akurat seingga kegiatan belajar mengajar bisa tercapai dengan maksimal. Permasalahan yangditemukan era sekarang ialah dari segi kemandirian belajar murid, yang memiliki nilai rendah di dalam kelas, maka akan menyebabkan siswa sulit mengatur waktu dalam belajar, tidak dapat mengatur tujuan yang hendak dicapai serta tidak bisa melangkah yang harus diperbuat dalam menyelesaikan tugas dari seorang guru.

Mewujudkan hal tersebut perlu adanya kemauan yang tinggi dari setiap siswa. Siswa terkadang kebingungan pada saat belum mengerti tetang pelajaran yang diberikan oleh guru dikarenakan kurang fokus dan kurang teliti terhadap persoalan yang dihadapi saai itu.

Maka perlu adanya kemandirian belajar dan cara atau upaya agar siswa mampu meningkatkan kemampuan daya berpikir secara responsif. Cara inilah yang bisa memberikan pemahaman agar bisa meningkatkan daya berfikir siswa/

Menurut penulis, ada beberapa cara agar siswa tetap meningkatkan daya berpikir antara lain :

(1) Rajin membaca buku. Siswa dengan membaca buku, maka bisa meningkatkan kualitasnya. (2) Sering mempelajari kembali materi yang disampaikan oleh guru sebelumnnya. Siswa bisa meringkas bahan pelajaran sebelumnnya. (3) Memakai kata singkatan agar mudah untuk mengingat. Siswa bisa mempermudah dengan mempersingkat kata agar tetap bisa menghafal sampai selamanya.

Sumber data yang diperoleh dari Falah Yunus, 2011 dengan judul "Korelasi Antara Sikap Terhadap Model Pembelajaran Inkuiri Dan Kemandirian Dengan Hasil Belajar Mata Pelajaran PKN Pada Materi Globalisasi Siswa Kelas IX SMP Negeri 50 Samarinda Tahun Pembelajaran 2010/2011. Hasil dari penelitian menemukan bahwa terdapat hubungan yang positif signifikan antara Sikap Terhadap Model Pembelajaran Inkuiri (X1) dengan Hasil Belajar Mata Pelajaran PKn Siswa (Y) dengan koefisien y1 $=0,362$ dan ditemukan persamaan regresi linier 0,235 X1 Y 5,570 seingga bisa meningkatkan kegiatan belajar mengajar

Keterkaitan dari data sebelumnya antara kemandirian belajar dengan model pembelajaran inkuiri adalah memiliki maksud dan arti yang sama yaitu bisa meningkatkan siswa agar tetap berusaha sendiri dengan berfikir secara analitis serta guru hanya sebagai fasilitator dan motivator, maka dengan itu sistem aktivitas pembelajaran dapat berlangsung sangat terarah serta sempurna. Jadi kemandirian belajar dan model pembelajaran inkuiri ini benar-benar cocok untuk diaplikasikan pada setiap kalangan di sekolah, baik di tingkat dasar sampai di tingkat menengah atas 


\section{PENUTUP}

\section{Kesimpulan}

Berdasarkan permasalahan di atas, maka dapat menghasilkan suatu pemecahan masalah, antara lain sebagai berikut : (1) Guru harus memiliki ide atau inovasi untuk membuat keadaan kelas yang menggembirakan agar siswa semakin aman. Siswa akan terasa gembira dengan kondisi kelas tersebut. (2) Kemudian guru bisa memberikan tambahan jam sekolah bagi beberapa siswa yang memiliki nilai yang rendah seperti: bimbingan belajar agar bisa meningkatkan pengetahuan berfikir. Siswa dapat menambah pengalaman belajar dengan baik. (3) Setelah itu, Guru melakukan komunikasi melalui wali murid sehingga bisa mengetahui tingkah laku siswa selama di rumah. Siswa sudah memahami karakter yang dimilikinnya. (4) Guru memberikan edukasi atau pemahaman tentang pentingnya peran orang tua untuk memantau anak agar bersikap mandiri dalam belajar. Siswa sudah bisa menceritakan kejadian yang menjadi persoalan saat ini. (5) Selepas itu, bisa bertindak bersamasama dengan konselor untuk mengakhiri persoalan terhadap siswa yang nilainnya rendah. Siswa akan terasa terkurangi beban yang selama ini menjadi sosok yang menakutkan dan masalah bisa cepat teratasi.

\section{DAFTAR PUSTAKA}

[1] Abdul Majid. 2013. Strategi Pembelajaran. Bandung: PT. Remaja Rosdakarya

[2] Ade, Sanjaya. 2011. Model-model Pembelajaran. Jakarta: Bumi Aksara.

[3] Ambarjaya, Beni. 2012. Psikologi Pendidikan dan Pengajaran Teori dan Praktik. Jakarta: Buku Seru.

[4] Babari, S. 2012. Psikologi Belajar. Jakarta: PT. Rineka Cipta

[5] B.Uno, Hamzah.2012. Teori Motivasi dan Pengukurannya. Jakarta: PT. Bumi Aksara.

[6] Desmita. 2011. Psikologi Perkembangan Peserta Didik. Bandung. PT Remaja Rosdakarya
[7] Desmita. 2012. Psikologi Perkembangan Peserta Didik. Bandung: PT. Remaja Rosdakarya

[8] Djaali. 2017. Psikologi Pendidikan. Jakarta: PT Bumi Aksara.

[9] Embun. 2012. Banjir Embun. Retrieved from Penelitian Kepustakaan: http://banjirembun.blogspot.co.id/2012/04 /penelitian-kepustakaan.html

[10]Fatimah, Enung. 2010. Psikologi Perkembangan (Perkembangan Peserta Didik).Bandung: Pustaka Setia

[11] Hamdayama, Jumanta. 2014. Model dan Metode Pembelajaran Kreatif. Jakarta: Ghalia Indonesia

[12] Hamiyah, N. Dan M. Jauhar. 2014. Strategi Belajar-Mengajar di Kelas. Jakarta: Prestasi Pustaka.

[13]Hamruni. 2012. Strategi Pembelajaran. Yogyakarta: Insan Madani

[14]Haris Mudjiman. 2011. Manajemen Pelatihan Berbasis Belajar Mandiri. Yogyakarta: Pustaka Pelajar.

[15] Larasati, D. A. 2020. Pengaruh Model Discovery Learning Berbasis Higher Order Thinking Skill Terhadap Kemampuan Berpikir Kritis. Sintang. http://jurnal.stkippersada.ac.id/jurnal/inde x.php/VOX

[16] Mashuri Imam. 2012. Pengaruh Pembelajaran Berbasis Masalah Dan Inkuiri Ditinjau Dari Kemandirian Belajar Siswa Kelas X SMA Negeri Kabupaten Blora .Blora : JMEE Volume II Nomor 1

[17]M. Hosnan. 2014. Pendekatan Saintifik dan Kontekstual dalam Pembelajaran Abad 2. Bogor: Ghalia Indonesia.

[18]Ngalimun. 2012. Strategi dan Model Pembelajaran. Banjarmasin: Aswaja Pressindo

[19] Novehasanah. 2016 . Kelebihan dan Kelemahan Model Inkuiri. [Online]. Tersedia :http://novehasanah.blogspot.co.i d/2016/01/kelebihan-

kelemahanmodelinkuiri.html. di akses pada hari Senin 10 April 2017 pukul 14.00

[20]Panjaitan Marta .R. 2013. Pengaruh Metode Inkuiri Terhadap Hasil Belajar 
Matematika dari Kemandirian Belajar Siswa di SMP Negeri 3 Salatiga. Salatiga :

Universitas Kristen Satya Wacana

[21]Prawiradilaga. 2012. Wawasan Teknologi Pendidikan. Jakarta: Kencana Prenada Media Group.

[22] Sagala, Syaiful. 2011. Konsep dan Makna Pembelajaran. Bandung: Alfabeta.

[23] Suryandari, Savitri. 2020. Pengaruh Pola Asuh Orang Tua Terhadap Kenakalan Remaja. Flores

http://unikastpaulus.ac.id/jurnal/index.php ljipd

[24] Sugiyono. 2012. Metode Penelitian Kuantitatif Kualitatif dan $R \& D$. Bandung: Alfabeta.

[25] Susanti. 2014. Pengaruh Model Pembelajaran Inkuiri Terbimbing Terhadap Hasil Belajar Sains Biologi Siswa Kelas VIII SMP N 1 Ngawen: Yogyakarta.

[26] Syam, Muhammad Nur. 2015. Pengantar Filsafat Pendidikan. Malang: FIP IKIP.

[27] Yamin, M. 2013. Strategi dan Metode dalam Model Pembelajaran. Jakarta: Referensi (GP Press Group).

[28]Zed, M. 2014. Metode Penelitian Kepustakaan. Jakarta: Yayasan Obor Indonesia 